\title{
Elogio y recuerdo de dos bibliógrafos notables y una bibliografía ejemplar: la Bibliografía Mexica- na del Siglo XVI
}

os son los destacados bibliográfos que debemos recordar este
año en el que se cumple el cincuentenario de la segunda o nue-
va edición de la BibliografíaMexicanadd sigoXV I: Catálogorazo nadodelibrosimpresos en Méxicode1539 a 1600. Conbiografías deautoresy ctrasilustradiones preetidbdeunandiaia acerca delaintroduccióndelaimprenta enMéxico, publicada por el Fondo de Cultura Económica en 1954: don Joaquín García Icazbalceta (1825-1894) y don Agustín Millares Carlo (1893-1980). Qué puede decirse ya sobre personajes tan ilustres, además de añadirles el "don" que reservamos para las verdaderas figuras. Su legado es monumental y su erudición sólo está a la par que su humildad y la labor realizada a favor de nuestro patrimonio cultural del México del siglo XVI. Su trabajo sigue siendo “...el espíritu oculto y benefactor que da comienzo a toda investigación” que se intente sobre ese periodo.

Cómo agradecerle a don Joaquín su interés por la historia de nuestro periodo colonial que lo llevó a recopilar y estudiar los originales de la época y a dedicarse al siglo XVI por considerarlo el periodo más interesante e importante de nuestra historia. Su amor por la historia lo llevó a recuperar, registrar, conservar y difundir los impresos mexicanos del siglo XVI "porque en él desaparecía un pueblo antiguo y se formaba otro nuevo; el mismo que existe en nuestros días y del que formamos parte". Y porque advertía con gran visión que esos documentos eran fundamentales para el estudio de la cultura, las costumbres y la política de ese pasado que transcurría, la historia de México.

De formación autodidacta, Don Joaquín fue un hombre de gran erudición que dedicó 40 años de su vida a reunir la información y los documentos que lo llevaron a escribir la primera bibliografía moderna 
sobre la producción tipográfica mexicana del siglo XVI, que en adelante servirá de modelo a los bibliógrafos mexicanos, Vicente de P. Andrade y Nicolás León, y al chileno José Toribio Medina, quienes realizaron sus obras siguiendo el ejemplo de su Bibliografía desde entonces y hasta ahora, reconocida internacionalmente.

De Don Agustín Millares Carlo cabe decir que era un notable intelectual del exilio español, y que al ser invitado por don Daniel Cosío Villegas para celebrar los 30 años de existencia del Fondo de Cultura Económica, realizó la nueva edición de la Bibliografía, en 1954, a la que añadió numerosos títulos y enriqueció con valiosos y eruditos comentarios. Sus aportaciones le consumieron más de diez años de dedicación y estudio, y le permitieron sumar los nuevos conocimientos que desde 1886 habían enriquecido los saberes mexicanos y extranjeros sobre esos importantes impresos. Así sus adiciones, correcciones, nuevas ilustraciones y un índice analítico renovaron la obra.

Este mundo actual es por entero diferente al de don Joaquín y también al de don Agustín, sin embargo la recuperación, el registro, el fácil acceso y la difusión de una gran parte del patrimonio documental de México, que comprende no sólo la época novohispana sino también los siglos XIX y XX, sigue siendo una tarea que todavía debe acometerse.

Que este comentario sea una invitación a recordar y reconocer a quienes magistralmente divulgaron los impresos mexicanos del siglo XVI, memoria invaluable de México. 